\title{
Fibronectin and Factor VIII-Related Antigen in Liver Cirrhosis and Acute Liver Failure
}

\author{
By H. Höfeler and H.-G. Klingemann \\ Zentrum für Innere Medizin, Medizinische Klinik und Poliklinik, Abteilung für Innere Medizin, \\ Schwerpunkt Hämatologie, Onkologie, Immunologie, Marburg/Lahn
}

(Received October 15, 1982/September 9, 1983)

Summary: The liver is involved in the turnover of fibronectin in two different ways: hepatic synthesis contributes substantially to the plasma fibronectin pool, while Kupffer-cells, performing an important role of the reticuloendothelial system, remove fibronectin opsonized material from the circulation.

In 45 patients with histologically confirmed liver cirrhosis and six patients with acute liver failure due to intoxication we determined fibronectin concentration in plasma by electroimmunoassay and additionally measured factor VIII-related antigen, which is a large glycoprotein not synthesized in the liver.

Fibronectin levels in plasma were decreased in liver cirrhosis. This decrease was correlated with the extent of porto-caval collateral circulation. Very low levels were found in patients with acute liver failure. Factor VIIIrelated antigen levels were greatly increased as a function of the hepatic insufficiency. Between both parameters there was a significant inverse correlation. It is concluded that the simultaneous determination of both proteins provides reliable information about the remaining liver function.

\section{Fibronectin und Faktor VIII-assoziiertes Antigen bei Lebercirrhose und akutem Leberversagen}

Zusammenfassung: Die Leber ist am Umsatz des Fibronectin im Plasma in zweierlei Hinsicht beteiligt: Die Fibronectinsynthese in der Leber liefert einen Teil des Fibronectins im Plasma, und Kupffer-Zellen entfernen als ein wichtiger Bestandteil des reticuloendothelialen Systems durch Fibronectin der Phagozytose zugänglich gemachtes Material aus der Blutbahn.

Wir untersuchten 45 Patienten mit der histologisch gesicherten Diagnose Lebercirrhose und sechs Patienten mit akutem Leberversagen nach Vergiftung. Fibronectin und Faktor VIII-assoziiertes Antigen, bei dem es sich ebenfalls um ein großes Glycoprotein handelt, das aber nicht in der Leber synthetisiert wird, wurden bei diesen Patienten im Plasma mittels Elektroimmunoassay bestimmt.

Fibronectin war im Plasma der Patienten mit Lebercirrhose vermindert. Diese Verminderung korrelierte mit dem Ausmaß eines porto-cavalen Shuntkreislaufs. Sehr niedrige Werte wurden bei akutem Leberversagen gemessen. Hingegen waren die K̇onzentrationen von Faktor VIII-assoziiertem Antigen im Plasma stark erhöht in Abhängigkeit von der Schwere der Erkrankung. Zwischen den Konzentrationen beider Glycoproteine im Plasma bestand eine umgekehrte Korrelation. Offensichtlich ist die gleichzeitige Bestimmung beider Kenngrößen geeignet, um Informationen über die verbliebene Leberfunktion der Patienten zu erhalten.

\section{Introduction}

Fibronectin is an adhesive and opsonic glycoprotein. In its soluble form it is present in plasma and other body fluids, whereas in its insoluble form it is found in interstitial connective tissue and in or close to basement membranes. Due to its specific binding to fibrin, collagen, heparin and bacteria etc., its function has been compared to that of a molecular glue (1). 
One of the important functions of fibronectin is that it acts as a mediator of phagocytosis by macrophages and endothelial cells of the reticuloendothelial system (2). Thus the term " $\alpha_{2}$-surface binding opsonic glycoprotein" has also been used to characterize its function. A deficiency of plasma fibronectin following trauma, burn and sepsis has been correlated with systemic failure of reticuloendothelial system function $(3,4)$. This, and the fact that fibronectin is synthesized in the liver (5), caused us to investigate plasma fibronectin levels in patients with liver failure. Simultaneously, the related large glycoprotein factor VIII-related antigen was measured, which in contrast to fibronectin, is not synthesized in the liver (6), but is said to be a reliable marker for the clearance function of the reticuloendothelial system (7).

\section{Materials and Methods}

Patients

Forty-five patients with histologically confirmed liver cirrhosis were subdivided according to the severity of hepatic insufficiency using the extent of the porto-caval collateral circulation. This parameter was evaluated by laparoscopy and radiology.

Group I, n = 10:

Patients without signs of porto-caval collateral circulation;

Group II, $\mathrm{n}=10$ :

Patients with porto-caval shunts: oesophageal varices, splenomegaly, reperfused umbilical veins and congested veins in ligamentum teres and ligamentum falciforme, as well as in the omentum maius;

Group III, $\mathrm{n}=25$ :

Patients with signs of decompensated liver cirrhosis (e.g. ascites or liver coma).

A further group consisted of 6 patients with acute liver failure due to intoxication. Thirty-five healthy persons with no history of liver disease ( 23 male, 12 female) and with an age distribution between 18 and 82 served as the control group.

\section{Collection of samples}

Venous blood was collected with sodium citrate as the anticoagulant. After centrifugation at $5000 \mathrm{~g}$ for 20 minutes, plasma was stored at $-34^{\circ} \mathrm{C}$ until used.

\section{Antisera}

Anti-fibronectin serum from rabbits, anti-antihaemophilic globulin (anti-factor VIII) related protein serum from rabbits, and protein standard plasma with a fibronectin concentration of $250 \mathrm{mg} / \mathrm{l}$ were obtained from Behringwerke AG, Marburg, West Germany.

\section{Electroimmunoassay}

Using the procedure of Laurell (8), electroimmunoassay was performed in a barbital buffer system ( $\mathrm{pH} 8.6$, ionic strength 0.02 ) on $5 \mathrm{~cm}$ square plates. An agarose gel $10 \mathrm{~g} / \mathrm{l}$ was used, containing 6.6 $\mathrm{ml} / \mathrm{l}$ anti-human fibronectin and anti-factor VIII-related protein, respectively. Four of the plates were run on a thermostated dish. At $1 \mathrm{~cm}$ intervals, wells $3 \mathrm{~mm}$ in diameter were cut into the gel and filled with $7 \mu \mathrm{l}$ of plasma dilutions to be assayed. Electrophoresis was performed at $6 \mathrm{~V} / \mathrm{cm}$ for 18 hours at $17^{\circ} \mathrm{C}$. The gels were then washed, dried and finally stained with Coomassie brilliant blue. A reference curve was set up using dilutions of the protein standard plasma with the known fibronectin concentration. For factor VIII-related antigen a pool of ten plasmas of healthy subjects served as reference. Our experience with this method resulted in a standard deviation of $\pm 8 \%$ and $\pm 1.0 .6 \%$ for factor VIII-related antigen and fibronectin, respectively, when the assays of the same sample were done on 8 different days.

\section{Crossed-immunoelectrophoresis}

Crossed-immunoelectrophoresis was performed on $10 \mathrm{~cm}$ square plates, according to Clarke \& Freeman (9); the first dimension at $12 \mathrm{~V} / \mathrm{cm}$ for 80 minutes and second dimension at $6 \mathrm{~V} / \mathrm{cm}$ for 15 hours. In the second dimension, the antiserum concentration of anti-fibronectin and anti-factor VIII-related protein was $6.6 \mathrm{ml} / \mathrm{l}$ agarose gel.

\section{Statistical analysis}

Means \pm standard deviation were computed from all data. Levels of significance were evaluated according to Student's t-test.

\section{Results}

The concentration of fibronectin in plasma of patients with liver cirrhosis was significantly decreased as soon as there were any signs of a porto-caval collateral circulation (tab. 1). There were also significant differences between the cirrhosis subgroups. The lowest plasma fibronectin levels were found in patients with acute liver failure.

Factor VIII-related antigen behaved quite differently. Its concentration was increased up to 20 -fold in patients with cirrhosis, this increase being a function of the severity of the disease, namely from subgroups I to III (tab. 2). Very high levels were also found in patients with acute liver failure.

Between the fibronectin and the factor VIII-related antigen plasma concentrations there was a significant negative correlation (fig. 1). We used crossed-immunoelectrophoresis with both antisera in the second dimension to demonstrate this relationship (fig. 2), thereby confirming that the high factor VIII-related antigen concentrations found in the electroimmunoassay were not due to a modified.electrophoretic mobility of an altered protein. 
Tab. 1. Plasma fibronectin levels in patients with liver disease. Fibronectin concentrations were measured by electroimmunoassay. Group 1 consisted of healthy persons without any signs or history of liver disease. The patients with liver cirrhosis were subgrouped according to the extent of porto-caval shunt. Acute liver failure in patients of group 5 was caused by intoxication. Mean values \pm standard deviation are given. Levels of significance were calculated using multiple Student's t-test.

\begin{tabular}{|c|c|c|c|}
\hline \multicolumn{2}{|c|}{ Patient group } & \multirow{2}{*}{$\begin{array}{l}\begin{array}{l}\text { Number } \\
\text { of patients }\end{array} \\
35\end{array}$} & \multirow{2}{*}{$\begin{array}{l}\begin{array}{l}\text { Plasma } \\
\text { fibronectin } \\
(\mathrm{mg} / \mathrm{l})\end{array} \\
259 \pm 34\end{array}$} \\
\hline 1 & Healthy subjects & & \\
\hline & Liver cirrhosis: & & \\
\hline 2 & Stage I & 10 & $238 \pm 34$ \\
\hline 3 & Stage II & 10 & $217 \pm 35^{a}$ \\
\hline 4 & Stage III & 25 & $167 \pm 76^{\text {a.b.c }}$ \\
\hline 5 & Acute liver failure & 6 & $133 \pm 87^{a, b}$ \\
\hline
\end{tabular}

a) $\mathrm{p}<0.005$ compared to Group 1

b) $p<0.005$ compared to Group 2

c) $\mathrm{p}<0.005$ compared to Group 3

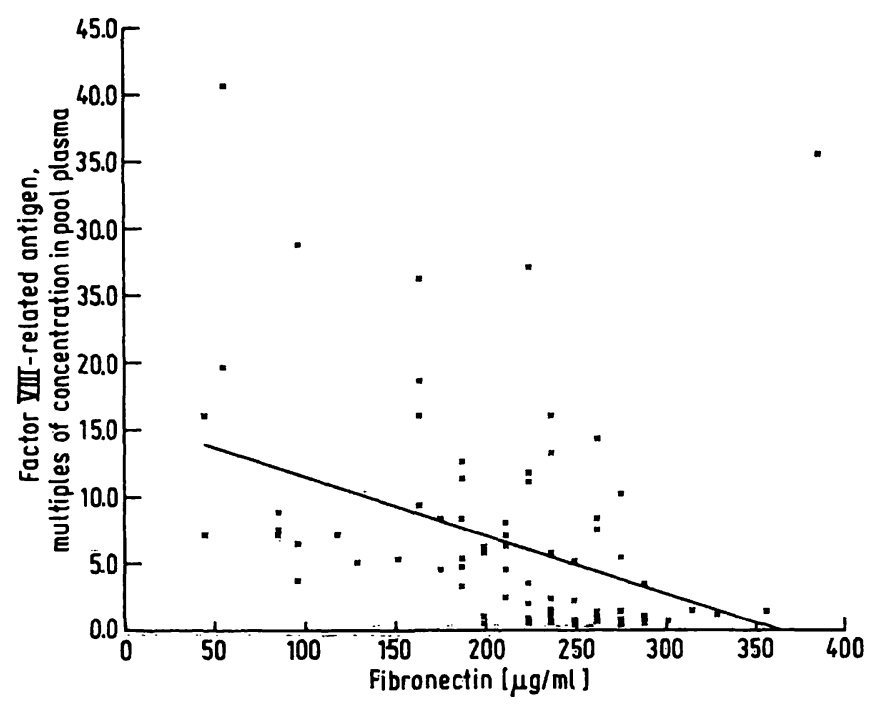

Fig. 1. Statistical evaluation of the correlation between the concentrations of fibronectin and factor VIII-related antigen in the plasmas of the patients in this study. $\mathrm{n}=86 ; \mathrm{r}=-0.3758 ; \mathrm{y} \doteq 15.88-0.0434 \mathrm{x} ; \mathrm{p}<0.001$

\section{Discussion}

Production sites of fibronectin in vivo are considered to be fibroblasts (10), vascular endothelial cells (11), and hepatocytes (12). A recent study on fibronectin synthesis in the perfused liver (5) indicates that hepatic synthesis contributes substantially to the plasma fibronectin pool. One property of the plasma fi-
Tab. 2. Factor VIII-related antigen in plasma of patients with liver disease.

Factor VIII-related antigen was determined by electroimmunoassay in the same patients as in table 1 . Because of the lack of a suitable standard, factor VIII-related antigen concentration in a plasma pool of healthy donors was set to 1.00 . Mean values \pm standard deviation are given. Levels of significance were calculated according to Student's t-test.

\begin{tabular}{|c|c|c|c|}
\hline \multicolumn{2}{|c|}{ Patient group } & \multirow{2}{*}{$\begin{array}{l}\begin{array}{l}\text { Number } \\
\text { of patients }\end{array} \\
35\end{array}$} & \multirow{2}{*}{$\begin{array}{l}\begin{array}{l}\text { Factor VIII- } \\
\text { related antigen }\end{array} \\
1.01 \pm 0.38\end{array}$} \\
\hline 1 & Healthy subjects & & \\
\hline & Liver cirrhosis: & & \\
\hline 2 & Stage I & 10 & $3.85 \pm 2.64^{a}$ \\
\hline 3 & Stage II & 10 & $6.91 \pm 2.50^{\mathrm{a} . \mathrm{b}}$ \\
\hline 4 & Stage III & 25 & $14.34 \pm 10.06^{\text {a.b.d }}$ \\
\hline 5 & Acute liver failure & 6 & $9.40 \pm 4.55^{a . c}$ \\
\hline
\end{tabular}

a) $\mathrm{p}<0.001$ compared to Group 1

b) $\mathrm{p}<0.001$ compared to Group 2

c) $p<0.005$ compared to Group 2

d) $\mathrm{p}<0.005$ compared to Group 3

bronectin is that it can bind to a large number of particles and macromolecules and mediate their opsonization by cells of the reticuloendothelial system. A deficiency of plasma fibronectin, as well as a depression of the reticuloendothelial system may impair its clearance function (13). This is observed in septicaemia, where the reticuloendothelial system is overloaded and the plasma fibronectin concentration is reduced (14). In this case a substitution of fibronectin was shown to improve the clinical state of the patients (15). Similar conditions may occur in patients with liver cirrhosis because the liver synthesizes part of the fibronectin, and Kupffer cells represent an important part of the reticuloendothelial system.

As presented in table 1, there was a significant decline of plasma fibronectin as soon as signs of a porto-caval shunt were found. The most striking reduction occurred in patients with acute liver failure, due to intoxication. In these patients haemostatic abnormalities of disseminated intravascular coagulation were also registered, which may have contributed to the drastic fall of fibronectin concentration. Our results regarding the cirrhosis patients seem to be in contradiction to earlier publications where elevated fibronectin levels were described (16), but the stages of liver cirrhosis we examined were different. We only found reduced levels of fibronectin in advanced disease, and all patients had an insufficiency of hepatic function. One explanation for the reduced fibronectin levels takes into consideration decreased 


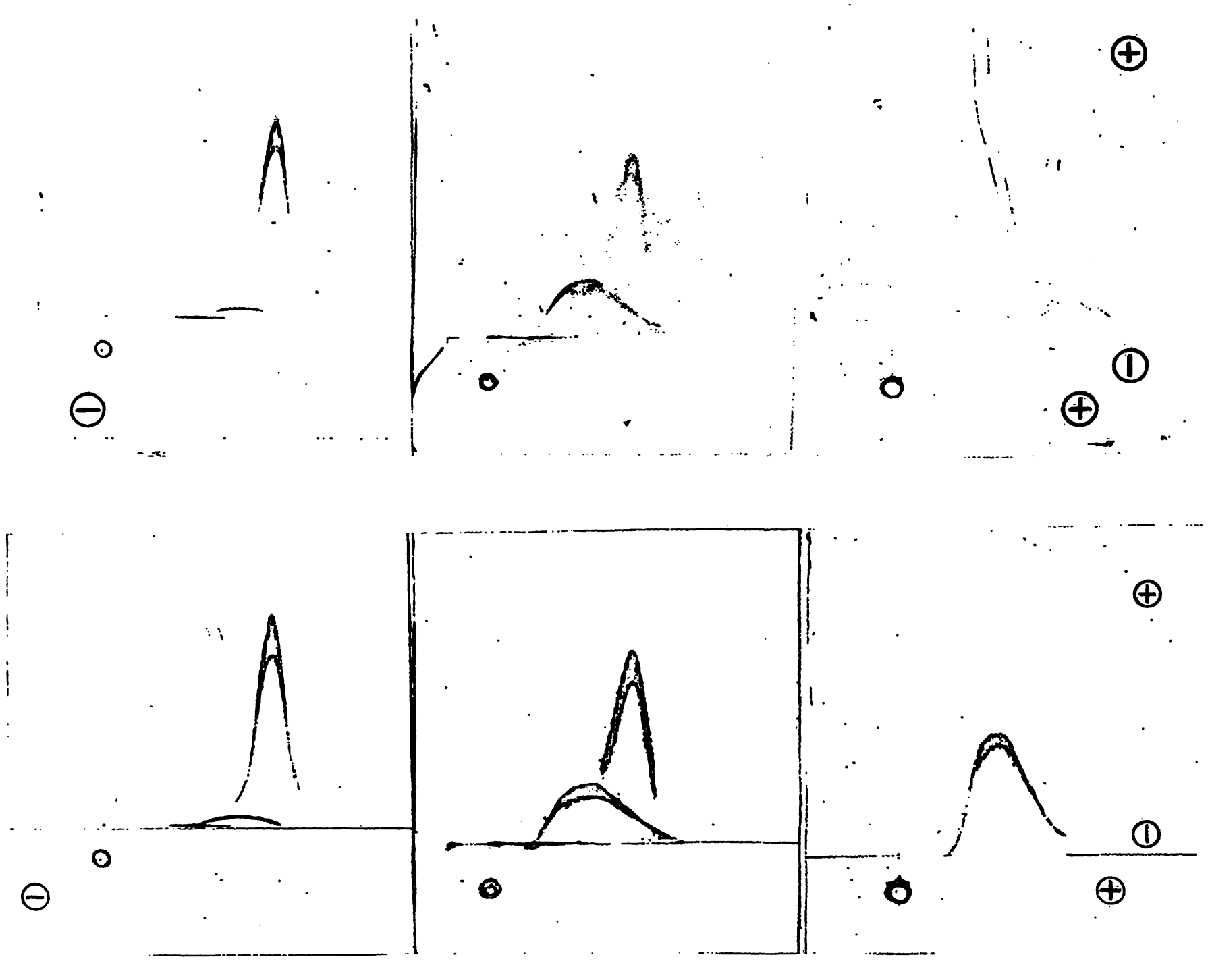

Fig. 2. Crossed-immunoelectrophoresis of patients with liver disease.

In the second dimension anti-fibronectin and anti-factor VIII-related antigen serum was present. From left to right a plasma from the cirrhosis stage I, stage III-group and from a patient with severe acute liver failure are shown. In addition to the high fibronectin peak, the slower migrating factor VIII-related antigen precipitate is seen to increase as the disease becomes more severe. The patient with acute liver failure showed the lowest fibronectin concentration of all examined patients, so that it was not even seen by this technique.

hepatic synthesis although there was a poor correlation to plasma albumin in our patients. Since it has been shown that fibronectin is susceptible to limited proteolysis by plasmin (17), an increased catabolism of fibronectin due to an accelerated fibrinolysis may have contributed to the reduced plasma levels.

Plasma levels of factor VIII-related antigen increased as a function of the severity of liver cirrhosis. Because this protein is not synthesized in the liver (6), we suppose that its increased plasma concentration reflects the depressed clearance function of the liver reticuloendothelial system (7). The possibility that this increase could be due to false results obtained by Laurell's technique caused by a modified mobility of an altered protein (18), was ruled out by using the two dimensional immunoelectrophoresis (fig. 2).

The simultaneous determination of the two related glycoproteins, fibronectin and factor VIIII-related antigen, in patients with liver disease may supply information about the synthesis and catabolism of fibronectin and the clearance function of the liver reticuloendothelial system. In cases with hepatic insufficiency and septic complications a substitution of fibronectin should be taken into consideration.

\section{Acknowledgement}

We wish to thank Ms. Jackie Solberg for her editorial and secretarial support. 


\section{References}

1. McDonagh, J. (1981) Arch. Pathol. Lab. Med. 105, 393396.

2. Blumenstock, F. A., Saba, T. M., Weber, P. \& Laffin, R. (1978) J. Biol. Chem. 253, 4287-4291.

3. Mosher, D. F. \& Williams, E. M. (1978) J. Lab. Clin. Med. 91, 729-735.

4. Lanser, M. E. \& Saba, T. M. (1982) Ann. Surg. 195, 340354.

5. Owens, M. R. \& Cimino, C. D. (1982) Blood 59, 45-52.

6. Shaw, E., Giddings, J. C., Peake, I. R. \& Bloom, A. L. (1979) Br. J. Haematol. 41, 585-596.

7. Brunswig, D. (1976) Habilitationsschrift, Würzburg.

8. Laurell, C. B. (1966) Anal. Biochem. 15, 45-52.

9. Clarke, M. H. G. \& Freeman, T. (1965) Clin. Sci. 35, 403413.

10. Jaffe, F. A. \& Mosher, D. F. (1978) J. Exp. Med. 147, 17791791.

.11. Saba, T. M. \& Jaffe, E. (1980) Amer. J. Med. 68, 577-594

12. Voss, B., Allam, S., Rauterberg, J., Ullrich, K., Gieselmann, V. \& Von Figura, K. (1979) Biochem. Biophys. Res. Commun. 90, 1348-1354.

13. Yamada, K. M. \& Weston, J. A. (1974) Proc. Nat. Acad. Sci. U.S. 71, 3492-3496.

14. Pott, G., Voss, B., Lohmann, J. \& Zündorf, P. (1982) J. Clin. Chem. Clin. Biochem. 20, 333-335.

15. Saba, T. M., Blumenstock, F. A., Scovill, W. A. \& Bernhard, H. (1978) Science 201, 622-624.

16. Pott, G., Meyering, M., Voss, B., Karges, H. E. \& Sieber, A. (1980) J. Clin. Chem. Clin. Biochem. 18, 893-895.

17. Jilek, F. \& Hörmann, H. (1977) Hoppe Seyler's Z. Physiol. Chem. 358, 133-136.

18. Maisonneuve, P. \& Sultan, Y. (1977) J. Clin. Pathol. 30, $221-227$

Dr. Herbert Höfeler

Department of Radiology

Beth Israel Hospital

330 Brookline Avenue

Boston, MA 02215, USA 
. 